Article

\title{
Determinants of Residents' Support for Sustainable Tourism Development: Implications for Rural Communities
}

\author{
Dunja Demirović Bajrami ${ }^{1,2, *}$, Adriana Radosavac ${ }^{3}{ }^{1}$, Marija Cimbaljević ${ }^{4}$, \\ Tatiana N. Tretiakova ${ }^{2}$ and Yulia A. Syromiatnikova ${ }^{2}$ \\ 1 Geographical Institute, "Jovan Cvijićc Serbian Academy of Sciences and Arts, 11000 Belgrade, Serbia \\ 2 Department of Tourism and Socio-Cultural Services, Institute of Sports, Tourism and Service, Federal State \\ Autonomous Educational Institution of Higher Education, South Ural State University, Chelyabinsk 454080, \\ Russia; ttn1@mail.ru (T.N.T.); syromiatnikovaya@susu.ru (Y.A.S.) \\ 3 Faculty of Applied Management, Economics and Finance, University Business Academy in Novi Sad, \\ 11000 Belgrade, Serbia; adrianaradosavac@gmail.com \\ 4 Department of Geography, Tourism and Hotel Management, Faculty of Sciences, University of Novi Sad, \\ 21000 Novi Sad, Serbia; marija.cimbaljevic@dgt.uns.ac.rs \\ * Correspondence: d.demirovic@gi.sanu.ac.rs
}

Received: 14 October 2020; Accepted: 9 November 2020; Published: 13 November 2020

\begin{abstract}
One of the key factors for success of sustainable tourism industry in all areas, including rural, is the support of community members. The paper aims to analyze how rural residents' perceptions of sustainable tourism development (expressed through economic, social, environmental, and physical benefits) can affect residents' intentions to support tourism. The second aim was to determine if attachment to the particular community and perceived quality of life can have influence on attitudes towards sustainable development of tourism in rural communities. Using a sample of 881 residents living in rural areas of the Republic of Serbia, the results highlighted that perceived values of tourism were important for evaluating how tourism is developed, if it is sustainable for a community, and how it affects quality of residents' life. The study provided better understanding of factors that can have impact on residents' attitudes in relation to tourism and highlighted the importance of paying attention to local community as significant player for tourism development, especially in those regions that want to boost its economy by developing sustainable tourism.
\end{abstract}

Keywords: sustainable rural tourism; community attachment; perceived values; quality of life; support for tourism development

\section{Introduction}

One of the key factors for success of the tourism industry in all areas, including rural, is the support of a local community [1,2]. Changes in residents' attitudes were important since they provided a way that planners and tourism practitioners should follow in order to achieve adequate level of community tourism development and planning. This adequate level was connected with satisfied quality of life, increased opportunities for new jobs, reduced costs of living, and finding ways of retaining younger population [3,4]. A few studies underlined that residents' sense of well-being and their sustenance for tourism development were connected with how the outcomes of tourism were evaluated by the members of a community $[5,6]$. This means that if residents perceive a positive benefit-cost ratio, it is more likely that they will support tourism and take active roles in tourism activities [7]. Economic benefits from tourism, like employment and economic gain, were used as indicators to examine community attachment, residents' quality of and satisfaction with life, and attitudes towards 
tourism $[8,9]$. Although economic benefits were a significant predictor, a combination of factors, such as social, emotional, and economic, performed better in analyzing how residents' perceived values influence quality of life, their satisfaction with life, and support for further tourism development [10-12]. According to Sweenev and Soutar [13], important aspects of tourism development were also those intangible values that can be derived from place attachment or personal benefits. Since communities may have different traditions, cultures and natural resources, residents' level of support and attitudes towards tourism development and perceived quality of life may depend on the nature of a destination. Furthermore, tourism can leave different effects on communities and these issues were especially important in developing countries. Development of tourism in rural areas aims to solve some problems like returning migration from urban areas to area of origin [14], to increase the stability of the active population through improving its living conditions [15], providing conditions for new economic and commercial activities [16,17], and protecting natural environment and local culture $[18,19]$ as sources for attracting tourists. Balanced growth of rural areas by tourism could be reached only if the improvement of living conditions of local community was a long-term goal and was expressed through economic, environmental, social, and cultural benefits. Additionally, if local people participate in tourism development, then its contribution to rural areas makes sense.

Rural development through tourism became an important concept for developed and developing countries, which is the case in Serbia, too. Although one of the main roles of the socio-economic development policies was to decrease the differences between rural and urban settlements, today's goal is more shifted towards interdependent development of agriculture and other business activities, such as tourism, by taking care of rural resources so they can be available for future generations $[20,21]$. In that manner, local development, with tourism, can represent a mobilization process that will involve innovations, will harmonize changes, and will be focused on increasing the opportunities available for population, economic growth, natural resources protection, and social equality [22]. The proliferation of tourism activities came as an accompanying process of economic and political reform, which involved opening up to the global market and building its own position on it, where tourism often had a very important role. At the same time, this process involved transforming the 'traditional' concepts of life, work, business, housing, etc., and was considered a period of intense social and cultural change [23].

The paper aims to analyze the rural community's support towards sustainable tourism development in Serbia, as a case study. The first task was to analyze how rural residents' perceptions of sustainable tourism development (expressed through economic, social, environmental, and physical benefits) can affect residents' intention to support tourism. The second aim was to determine if attachment to a particular community and perceived quality of life can have an influence on attitudes towards sustainable tourism development in the community. The research expands comprehension of attitudes towards tourism development by members of the local community. The members of local communities can be a base for tourism development, since they are most familiar with their needs and interests, and they control the most of the resources like land, buildings, local production, and customs, while their support is crucial for the successful and sustainable tourism development.

\section{Theoretical Framework and Research Hypotheses}

\subsection{Community Attachment}

Community attachment was viewed as identification with local community, dependence on that community and created bonds with its members [24]. It was an important element thatwas taken into account in tourism studies but also in practice when residents' support towards tourism development and their perceptions of tourism impact needed to be examined [25]. The analysis of residents' attachment to their communities and their resources may explain how residents interpret the influence of tourism, and this can be a significant determinant in providing aneffectual bond between residents and sustainable tourism development. Many scholars have achieved compliance that community attachment had a significant role in shaping residents' attitudes towards tourism development and 
their intention to preserve place characteristics [26-28]. The way in which residents experience their environment and create a bond with it influences residents' behavior [29], their intention to stay or move to other community, and their intention to support or reject development projects, including tourism [30]. Residents who were more attached to their community expressed support for further development of sustainable tourism through various activities such as organizing or meetings attendance, giving donations, or making suggestions for new or voting for the proposed tourism plans [31]. There was no consensus among scholars on the relationship between community attachment and support or impact of tourism development. While there were studies which showed that strongly attached residents perceived tourism in a positive manner, explaining that those residents probably looked on tourism as beneficial for their local economy [8,32], on the other side there were studies that highlighted that residents with strongly expressed community attachment tend to be less supportive towards development of tourism in their community, since those residents probably perceived tourism as a threat to a place where they live $[33,34]$. When it comes to relations with perceived positive tourism impacts, there was evidence that community attachment had positive and significant correlation with perceived benefits and, as such, had an indirect impact on support for tourism development [32]. Lee [8] indicated that community attachment affected perceived economic and social benefits, while it was not case for cultural benefits. Length of residency, as one of dimensions of community attachment, had negative relation with perception of tourism impact [34], whereas social bond with residents' place had positive relationship [6]. Ramkissoon, Weiler and Smith [35] underlined that a more comprehensive approach is desirable and that the components of community attachment like place identity and social bonding should be used when examining the link between attachment and perceptions of tourism development. Based on the reviewed literature, the following hypotheses were set:

Hypothesis 1 (H1). Residents' level of community attachment and their perception of positive tourism impacts on a rural community are connected, in a positive direction.

Hypothesis 2 (H2). Residents' level of community attachment and their tendency to support development of tourismin a rural community are connected, in a positive direction.

\subsection{Residents'Perceptions of Tourism Impact}

Many studies [1,2,9] have shown that support for tourism development, expressed by members of a local community, correlated with their perceptions of tourism benefits in a positive direction. On the contrary, if tourism impacts were perceived as negative, there was no support [36,37]. It was shown that, if residents had enough information about tourism development in their community and if they perceived tourism impact as positive, they were more willing to support tourism development in future and to make contact with tourists [38], while positive perception of tourism impacts positively influenced increased satisfaction with quality of life and residents' intention to be part of a value co-creation in their community [39]. The impact of perceived tourism benefits on support for tourism development and perceived quality of life was not the same, depending on the type of tourism benefits. Although it was evident that economic, socio-cultural, and environmental tourism benefits created positive relationships with support for tourism development and residents' perceived quality of life, the study of Stylidis et al. [40] in Kavala (a small community in Greece), indicated that perceived economic benefits had the strongest and the environmental benefits had the weakest impact, while this was the opposite in study carried out by Long and Kay at [41], who showed that residents of a small community in Vietnam were willing to support tourism mostly based on perceived socio-cultural and environmental benefits.

Socioeconomic factors like age, gender, income, level of education [9], and financial dependence on tourism [42] seem to be the key factors that correlate between residents' attitudes and support towards tourism development in rural areas. It was indicated that personal benefits can be a strong 
determinant in predicting the impacts of tourism, both positive and negative [2,43]. Perceived impact served as a predictor of residents' support for tourism development in rural areas in a short- or long-term period [44].

There are many ways in which tourism improved the residents' quality of life, but also quality of the whole area: tourism improved standards of living, increased the investment, upgraded facilities such as parks and traffic infrastructure, brought a chance to meet new people, expanded knowledge about the world, etc. [45]. Positive impacts of tourism, observed through socio-cultural, environmental, and economic aspects, contributed to the better quality of residents' life, but on the other side, negative impacts decreased it $[10,45]$. Some research found positive relationship between residents' perceptions of tourism and their satisfaction with quality of their life [46,47]. Increased perception of life quality was mostly connected with those community sources (like safety, traffic infrastructure, recreation activities, etc.) that can be influenced by tourism development but can be shared between tourists and local residents [48]. Impact of perceived tourism benefits on perceived overall quality of life mostly overpowered the perception of negative tourism effects and this was highlighted regardless of the type of tourism [49]. Since it was shown that residents' perceptions were an important determinant for the sustainable development of tourism, the following hypotheses were proposed:

Hypothesis 3 (H3). Rural residents' positive perception of tourism benefits and their tendency to support development of sustainable tourism are connected, in a positive direction.

Hypothesis 4 (H4). Rural residents' positive perception of tourism benefits will have impact on how they perceive overall quality of their lives, in a positive direction.

\subsection{Overall Quality of Residents' Life}

Development of sustainable tourism in most of the communities, especially rural, was mostly initiated with the aim of improving residents' quality of life. A connection among quality of residents' life and their support for tourism development was examined in several studies $[10,45,50]$. Tourism development can affect different aspects of residents' life such as material status, emotional life, ties with family, personal health, and a sense of security [45]. All of these aspects had impact on their perception of the overall satisfaction with quality of life in a community where they live, and thus on their intention to support tourism development [51]. The impact of tourism on satisfaction with personal life, and satisfaction with neighbors and the wider community were taken into consideration when analyzing residents' perceptions of quality of their life [52]. Tourism products created for visitors, such as festivals, special attractions, and opportunities for recreation, can enhance residents' quality of life if they are available to them and, on the other side, improved standard of living and new job opportunities can also lead to higher satisfaction with the quality of life. Jeon, Kang, and Desmarais [53] highlighted that only those types of tourism or tourism products and services should be developed in some local community if they will not decrease residents' quality of life. Research conducted among rural residents in Poland [54] showed that psychological empowerment, as a component of quality of life, was one of the most important predictors of residents' support for tourism development, and that factor even had a higher impact than economic benefits gained from tourism development. In a research conducted by McGehee and Andereck [9], it was found that personal and community's benefits obtained from tourism influenced residents to support tourism development, i.e., if tourism development affected local economy in a positive way (for example, created new jobs), residents will support its further development. Although it was shown that perceived perceptions of quality of life had impact on residents support for tourism development, there were differences among residents. For example, families with small children and those who lived for many years in Istria (Croatia) believed that the quality of their lives will be reduced with further tourism development [55], while in Hungary, only those who felt direct effects of tourism development reported stronger improvement in the quality 
of life and more easily supported tourism development in their community [56]. The above-mentioned studies showed that quality of residents' life had an impact on their perspective when it came to development of tourism in their community, but there was research of Nunkoo and Fung [57] that could not find a connection between these two constructs, so there is a need for further analysis in order to better understand this relationship. The following hypothesis was proposed:

Hypothesis 5 (H5). Perceptions of the overall quality of rural residents' life have an impact on their support for tourism development.

\section{Materials and Methods}

\subsection{Study Area}

Rural areas in Serbia occupy 85\% of its total area. According to the last official census in 2011, $40.56 \%$ of the population lived in rural areas (2,914,990 inhabitants) [58]. The density of population in rural areas is 63 inhabitants per $\mathrm{km}^{2}$ and by one-third is lower than the national average. Rural areas contributed to $40 \%$ of the GDP of Serbia. However, rural areas are faced with many problems, such as reduction in the number of farmers, younger people moving to cities causing the majority of the households in rural areas to be elderly households, while the expansion of industrial areas has led to a reduction in arable land [59]. During the last two decades, the agricultural sector in the Western Balkan experienced a huge decline that was forced to perform a social function. This caused the appearance of a large number of small family farms that produced only for their own needs and that hardly survived. Since agriculture is no longer the main sector that creates most of the jobs and incomes, other solutions, in form of different policies, were necessary to increase the productivity of the agriculture sector. Tourism has become one of the main driving forces in guiding rural area toward sustainable development [60-62]. Policymakers increasingly understood that rural development policies were needed because they can contribute to improving the social and financial status of rural residents and lead to more efficient use of resources available to rural areas and their communities [63].

\subsection{Research Instrument}

The questionnaire (available as a Supplementary Materials) used in the research contained five sections. The scales presented by Abdollahzadeh and Sharifzadeh [64] and Gursoy and Rutherford [6] were used to analyze perceptions of rural residents towards the tourism development in their communities. The rural residents' perceptions were analyzed through perceived benefits of tourism development: economic benefits (seven items), social benefits (five items), environmental benefits (two items), and physical benefits (three items). In the second section, the overall quality of residents' life was measured with three items created by Wo, Kim, and Uysal [10]. The aim of the third section was to analyze residents' intention to support tourism development. The scale used for this section contained six items that came from study carried out by Wo, Kim, and Uysal [10], and Nicholas, Thapa and Ko [65]. For the fourth section, nine items were used to express rural residents' attachment to their community and those items were drawn from Lee's [8] research. The responses in all four sections were scored on a five-point Likert scale (1-totally disagree, 5-totally agree). Finally, the last section included demographic characteristics of the respondents such as gender, age, education level, and length of residence in a rural area. Those characteristics were used to create the respondents' profiles.

\subsection{Sampling and Surveying}

Collection of the field data was carried out by a stratified random-sampling method. Based on data collected from local tourist organizations in Serbia, twenty rural communities, that have developed some type of tourism, were selected for this study. Authors trained ten graduated students to collect the survey data. Trained students approached the potential respondents at the places of their residence 
by visiting every house in the rural community and interviewing interested household members aged over 18, one by one, face to face. Most of the rural communities had between 1000 and 3000 residents. If the students could not find someone at home, they left the envelope with the questionnaire and instructions (how to fill in the questionnaire) and asked them to leave the questionnaire at the nearest municipality offices. Interviewing was done mostly during weekends, from September to November 2019. The return rate was around $52 \%$ and, in total, 881 questionnaires were collected and used in further analyses. The summary measures were reported as mean difference with $95 \%$ confidence intervals, providing the information about a range within which the $95 \%$ sample means will fall.

\subsection{Data Analysis}

SPSS Statistics Version 23.0 for Windows was used for all analyses. The analysis had two steps. In the first step, the measurement model was analyzed, while in the second, the structural model. The partial least squares (PLS) were used to reduce the predictors to a smaller set of uncorrelated components and perform least squares regression on these components. This technique was useful in showing if the measurement model was effective. For all proposed variables, composite reliability was higher than 0.70 . The values of convergent validity and composite reliability for all four constructs-rural residents' perceptions, attachment to a community, overall quality of residents' life, and residents' support for tourism development-were useful to increase the quality of the measurement model. The values of discriminant validity were used to secure that the outcomes of correlations among the variables were lower than the square of the average variance extracted. The values of R-squared for each dependent construct were used to assess the structural model (the results were indicators for each dimension). In order to accept or reject the proposed hypotheses, the direction and significance of the constructs were taken into account. The variables achieved weak to moderate connections and the percentage of explained variance was presented.

\section{Results and Discussion}

\subsection{Profile of the Sample}

As presented in Table 1, the sample was consisted of $56.3 \%$ female and $43.7 \%$ male respondents. The largest percentage of the sample was between 47 and 67 years old (39.9\%). The division of the results by the level of education showed that most respondents have finished secondary school ( $47.1 \%)$. When it comes to the respondents' status, the majority of them were retired (37.4\%) or unemployed $(28.9 \%)$. The largest group of the respondents had lower family income-between EUR 200 and $400(42.6 \%)$. Most of the respondents $(40.2 \%)$ have been living in their villages for over 30 years. These results indicated that the demographic and economic structure of the sample does not differ too much from the overall rural population in Serbia or from most of the European countries.

Table 1. Profile of the sample.

\begin{tabular}{cccccc}
\hline Gender & $\mathbf{\%}$ & Age & $\mathbf{\%}$ & Education & $\mathbf{\%}$ \\
\hline Male & 43.7 & Less than 25 & 12.0 & Primary school & 22.1 \\
Female & 56.3 & $26-46$ & 32.5 & Secondary school & 47.1 \\
& & $47-67$ & 39.9 & Faculty & 30.8 \\
& & Over 67 & 15.6 & & \\
\hline Status & $\%$ & Income per Month (€) & $\mathbf{\%}$ & Living in a Village for: & $\mathbf{\%}$ \\
\hline Student & 12.1 & Less than 200 & 16.1 & Less than 10 years & 13.3 \\
Unemployed & 28.9 & 200-400 & 42.6 & $10-20$ & 19.1 \\
Employed & 21.6 & $401-600$ & 26.9 & $21-30$ & 27.4 \\
Retired & 37.4 & More than 600 & 14.4 & Over 30 years & 40.2 \\
\hline
\end{tabular}




\subsection{Model Analysis Results}

Ciavolino and Nitti [66] suggested that if a model includes more dimensions (in this paper, there were four dimensions), authors should, in the first step, analyze the measurement model, while in the second step it should be the structural model. Following these recommendations and steps proposed by Wright et al. [67], variables were seen as meditative. The partial least squares were used to assess the model.

\subsubsection{Analysis of the Measurement Model-First Step}

Hair, Ringle, and Sarstedt [68] indicated that, for the internal consistency reliability, composite reliability should be higher than 0.70 (although values between 0.6 and 0.7 can also be found as satisfying), while each indicator's absolute standardized loadings should be also higher than 0.70. Following these recommendations, three items were excluded-one item from the scale "Economic benefits" (refers to creating opportunities for investments, $\lambda=0.3177$ ), one from the scale "Social benefits" (contact among local residents and tourists can boost awareness that tourism development is significant for the community, $\lambda=0.4672$ ), and one item from the scale "Attachment to rural community" (refers to how much local residents identify their lives with living in a particular community, $\lambda=0.3994$ ). Only one item (from the scale "Social benefits", number 5) had loadings below 0.7 , but we decided to leave this item since its removal or retention did not significantly affected validity. As shown in Table 2, the scores of average variance extracted (AVE) for all variables were above 0.5 , indicating that these variables were valid for further analysis.

Table 2. Results of the first step-evaluation of the measurement model.

\begin{tabular}{|c|c|c|c|c|c|c|}
\hline Variables & Mean & Std. Deviation & Loadings & $t$-Test & $\mathbf{C R}^{*}$ & AVE ** \\
\hline $\begin{array}{l}\text { Perceptions of tourism benefits } \\
\text { (economic benefits) (PTBE) }\end{array}$ & & & & & 0.78 & 0.5360 \\
\hline $\begin{array}{l}\text { (1) Demand for farm products is } \\
\text { increased due to tourism. }\end{array}$ & 4.17 & 0.633 & 0.6989 & 9.0668 & - & - \\
\hline $\begin{array}{l}\text { (2) The number of jobs for the local } \\
\text { residents has increased due tourism. }\end{array}$ & 4.03 & 0.610 & 0.7526 & 14.732 & - & - \\
\hline $\begin{array}{l}\text { (3) Incomes of local community are } \\
\text { increased due to tourism. }\end{array}$ & 4.14 & 0.751 & 0.7168 & 13.5646 & - & - \\
\hline $\begin{array}{l}\text { (4) Local products are sold more due } \\
\text { to tourism. }\end{array}$ & 4.06 & 0.721 & 0.7588 & 22.054 & - & - \\
\hline $\begin{array}{l}\text { (5) Rural economy is diversified due } \\
\text { to tourism. }\end{array}$ & 4.09 & 0.665 & 0.7346 & 15.8845 & - & - \\
\hline $\begin{array}{l}\text { (6) Profitability of local businesses is } \\
\text { enhanced due to tourism. }\end{array}$ & 3.97 & 0.774 & 0.6916 & 14.0756 & - & - \\
\hline $\begin{array}{l}\text { Perceptions of tourism benefits } \\
\text { (social benefits) (PTBS) }\end{array}$ & & & & & 0.85 & 0.546 \\
\hline $\begin{array}{l}\text { (1) Standards of living are improved due } \\
\text { to tourism. }\end{array}$ & 3.69 & 0.764 & 0.7236 & 12.754 & - & - \\
\hline $\begin{array}{l}\text { (2) Respect for local culture is enhanced } \\
\text { due to tourism. }\end{array}$ & 3.41 & 0.742 & 0.7488 & 17.5887 & - & - \\
\hline $\begin{array}{l}\text { (3) Opportunities to participate in local } \\
\text { activities are increased due to tourism. }\end{array}$ & 3.48 & 0.803 & 0.7585 & 19.1138 & - & - \\
\hline $\begin{array}{l}\text { (4) The sense of belonging to the local } \\
\text { community is stronger due to tourism }\end{array}$ & 3.33 & 0.737 & 0.7699 & 20.3556 & - & - \\
\hline $\begin{array}{l}\text { (5) Number of learning opportunities is } \\
\text { increased due to tourism. }\end{array}$ & 3.57 & 0.821 & 0.6753 & 14.9345 & - & - \\
\hline
\end{tabular}


Table 2. Cont.

\begin{tabular}{|c|c|c|c|c|c|c|}
\hline Variables & Mean & Std. Deviation & Loadings & $t$-Test & $\mathbf{C R}^{*}$ & AVE $* *$ \\
\hline $\begin{array}{l}\text { Perceptions of tourism benefits } \\
\text { (environmental benefits) (PTBN) }\end{array}$ & & & & & 0.79 & 0.5221 \\
\hline $\begin{array}{l}\text { (1) Tourism encourages the protection } \\
\text { of the natural environment. }\end{array}$ & 3.84 & 0.752 & 0.8887 & 21.6518 & - & - \\
\hline $\begin{array}{l}\text { (2) More areas have been declared as } \\
\text { protected due to tourism. }\end{array}$ & 3.54 & 0.843 & 0.7848 & 8.8879 & - & - \\
\hline $\begin{array}{l}\text { Perceptions of tourism benefits } \\
\text { (physical benefits) (PTBP) }\end{array}$ & & & & & 0.76 & 0.5524 \\
\hline $\begin{array}{l}\text { (1) Tourism affects the increase in local } \\
\text { real estate value. }\end{array}$ & 3.83 & 0.722 & 0.7831 & 14.3158 & - & - \\
\hline $\begin{array}{l}\text { (2) Amount of investments in tourism } \\
\text { infrastructure increases due to tourism. }\end{array}$ & 3.67 & 0.754 & 0.8443 & 17.7753 & - & - \\
\hline $\begin{array}{l}\text { (3) Amount of investments in local } \\
\text { infrastructure increases due to tourism. }\end{array}$ & 3.18 & 1.111 & 0.7847 & 7.0667 & - & - \\
\hline Attachment to rural community (ARC) & & & & & 0.90 & 0.5542 \\
\hline $\begin{array}{l}\text { (1) The settings and facilities in } \\
\text { community are excellent. }\end{array}$ & 3.71 & 0.653 & 0.7261 & 13.1005 & - & - \\
\hline $\begin{array}{l}\text { (2) I favor living in my community } \\
\text { over other communities. }\end{array}$ & 3.89 & 0.674 & 0.7352 & 13.3442 & - & - \\
\hline (3) I like living in this community. & 4.01 & 0.662 & 0.7538 & 14.5985 & - & - \\
\hline $\begin{array}{l}\text { (4) Living in my community reflects } \\
\text { who I am. }\end{array}$ & 4.09 & 0.765 & 0.7544 & 18.3716 & - & - \\
\hline $\begin{array}{l}\text { (5) It means a lot to me to live in } \\
\text { this community. }\end{array}$ & 4.10 & 0.754 & 0.7724 & 19.9178 & - & - \\
\hline $\begin{array}{l}\text { (6) I am very attached to the place } \\
\text { where I live. }\end{array}$ & 4.13 & 0.787 & 0.7781 & 22.5386 & - & - \\
\hline (7) I feel I belong to my community. & 4.05 & 0.813 & 0.7715 & 21.3174 & - & - \\
\hline $\begin{array}{l}\text { (8) People I know favor our community } \\
\text { over others. }\end{array}$ & 3.85 & 0.646 & 0.7382 & 9.3837 & - & - \\
\hline Quality of residents' life $(Q L)$ & & & & & 0.89 & 0.7390 \\
\hline $\begin{array}{l}\text { (1) I am satisfied with the conditions } \\
\text { of my life. }\end{array}$ & 3.71 & 0.782 & 0.8337 & 33.4543 & - & - \\
\hline (2) I have all things I wanted in my life. & 3.52 & 0.811 & 0.8848 & 59.2812 & - & - \\
\hline (3) In general, I am satisfied with my life. & 3.54 & 0.891 & 0.8682 & 48.4750 & - & - \\
\hline Support for tourism development (STD) & & & & & 0.86 & 0.6269 \\
\hline $\begin{array}{l}\text { (1) I am happy to support the } \\
\text { development of tourism initiatives that } \\
\text { are sustainable for my community. }\end{array}$ & 4.32 & 0.844 & 0.7182 & 13.3268 & - & - \\
\hline $\begin{array}{l}\text { (2) I am willing to take active } \\
\text { participation in creation of plans and } \\
\text { strategies connected with tourism. }\end{array}$ & 3.91 & 0.731 & 0.7726 & 26.8588 & - & - \\
\hline $\begin{array}{l}\text { (3) I am willing to take active part in } \\
\text { cultural exchanges with visitors. }\end{array}$ & 3.61 & 0.693 & 0.7123 & 15.5841 & - & - \\
\hline $\begin{array}{l}\text { (4) I am willing to take part in promoting } \\
\text { environmental education and } \\
\text { conservation initiatives. }\end{array}$ & 3.55 & 0.584 & 0.7006 & 12.6730 & - & - \\
\hline $\begin{array}{l}\text { (5) I would support further tourism } \\
\text { development in my community. }\end{array}$ & 4.16 & 0.676 & 0.8556 & 40.1211 & - & - \\
\hline $\begin{array}{l}\text { (6) I believe that tourism development } \\
\text { will positively affect quality of all } \\
\text { residents' life. }\end{array}$ & 4.24 & 0.712 & 0.8176 & 21.4146 & - & - \\
\hline
\end{tabular}


In Table 3, values of discriminant validity were used to secure that the outcomes of correlations among the variables were lower than the square of the average variance extracted. The results showed that the measurement model was well founded and valid, so the next step could be implemented.

Table 3. Results of the first step for the discriminant validity.

\begin{tabular}{cccccccc}
\hline & ARC & STD & QL & PTBE & PTBP & PTBN & PTBS \\
\hline ARC & 0.7311 & & & & & & \\
STD & 0.4887 & 0.7976 & & & & & \\
QL & 0.3768 & 0.5145 & 0.8646 & & & & \\
PTBE & 0.4988 & 0.5046 & 0.3888 & 0.6931 & & & \\
PTBP & 0.4643 & 0.4019 & 0.2015 & 0.4628 & 0.7539 & & \\
PTBN & 0.3955 & 0.3576 & 0.2266 & 0.4892 & 0.4005 & 0.7081 & \\
PTBS & 0.3084 & 0.4561 & 0.2374 & 0.5884 & 0.3936 & 0.3904 & 0.7239 \\
\hline
\end{tabular}

Note: ARC-Attachment to rural community; STD—Support for tourism development; QL-Quality of residents'life; PTBE—Economic benefits; PTBP—Physical benefits; PTBN—Environmental benefits; PTBS—Social benefits.

\subsubsection{Results of the Second Step for the Proposed Model}

In this step, the aggregate scores, calculated using PLS from the previous step, were utilized to construct the model of the second level. The results were indicators for each dimension. In Table 4, results of items' individual and composite reliability are presented. The scores were over the critical values, which are in accordance with the recommendation of MacKenzie, Podsakoff, and Jarvis [69].

Table 4. Results of the second step for the proposed model.

\begin{tabular}{lcccc}
\hline \multicolumn{1}{c}{ Variables } & Loadings & $\boldsymbol{t}$-Test & CR & AVE \\
\hline Perceptions of rural tourism & & & 0.8414 & 0.5827 \\
benefits & & & - & - \\
Economic benefits & 0.8543 & 26.3422 & - & - \\
Social benefits & 0.7487 & 17.1416 & - & - \\
Environmental benefits & 0.7134 & 13.0112 & - & - \\
Physical benefits & 0.7213 & 12.7658 & - & 0.5594 \\
\hline Attachment to rural community & & & 0.9264 & - \\
ARC1 & 0.7349 & 12.2705 & - & - \\
ARC2 & 0.7428 & 14.5036 & - & - \\
ARC3 & 0.7281 & 13.6325 & - & - \\
ARC4 & 0.7347 & 12.5816 & - & - \\
ARC5 & 0.7531 & 18.1425 & - & - \\
ARC6 & 0.7705 & 19.9163 & - & - \\
ARC7 & 0.7769 & 22.9872 & - & - \\
ARC8 & 0.7435 & 21.4136 & - & - \\
ARC9 & 0.6628 & 9.5229 & - & - \\
\hline Quality of Residents' Life & & & 0.8874 & - \\
QL1 & 0.8563 & 33.6526 & - & - \\
QL2 & 0.8864 & 58.6228 & - & - \\
QL3 & 0.8473 & 43.6985 & - & - \\
\hline Support for Tourism Development & & & 0.8655 & - \\
STD1 & 0.6931 & 26.8552 & - & - \\
STD2 & 0.8528 & 38.0243 & - & - \\
STD3 & 0.7265 & 22.9366 & - & - \\
STD4 & 0.6485 & 14.1265 & - & - \\
STD5 & 0.7258 & 20.3680 & - & - \\
STD6 & 0.7806 & 12.8523 & - & - \\
\hline & & & - \\
\hline
\end{tabular}

Note: *CR-Composite Reliability, ${ }^{* *}$ AVE-Average Variance Extracted. 
After the second step was done, it can be indicated that the model had an adequate validity and that it was reliable and valid (Table 5). Results obtained in these two steps showed that authors can proceed with next step-analysis of the structural model.

Table 5. Results of the second step for the discriminant validity.

\begin{tabular}{lcccc}
\hline & $\begin{array}{c}\text { Attachment to } \\
\text { Rural Community }\end{array}$ & $\begin{array}{c}\text { Support for Tourism } \\
\text { Development }\end{array}$ & $\begin{array}{c}\text { Quality of } \\
\text { Residents' Life }\end{array}$ & $\begin{array}{c}\text { Perceptions of Rural } \\
\text { Tourism Benefits }\end{array}$ \\
\hline Attachment to rural community & 0.7533 & & & \\
Support for tourism development & 0.4682 & 0.7883 & & \\
Quality of residents' life & 0.3796 & 0.4531 & 0.8744 & 0.7584 \\
Perceptions of rural tourism benefits & 0.5233 & 0.5406 & 0.3781 & \\
\hline
\end{tabular}

\subsection{Structural Model Assessment}

As can be seen in Table 6, variables achieved weak to moderate connections. The variable "Support for tourism development" had the highest explained variance, since this model could describe $48.9 \%$ of this variable. It was primarily influenced by the quality of life $(22.2 \%)$, while the lesser impact was connected with community attachment $(7.4 \%)$.

Table 6. Results of direct effects among variables.

\begin{tabular}{|c|c|c|c|c|}
\hline Hypothesis & $\mathbf{R}^{2}$ & $\begin{array}{l}\text { Direct } \\
\text { Effect }\end{array}$ & Correlation & $\begin{array}{c}\text { Explained } \\
\text { Variance }\end{array}$ \\
\hline Perceptions of rural tourism benefits & 0.2614 & / & / & $29.1 \%$ \\
\hline $\mathrm{H} 1(+)$ : Attachment to rural community $\rightarrow$ Perceptions of rural tourism benefits & / & 0.5488 & 0.5488 & $29.1 \%$ \\
\hline Quality of residents'life & 0.1643 & / & / & $12.8 \%$ \\
\hline H4(+):Perceptions of rural tourism benefits $\rightarrow$ Quality of residents'life & / & 0.458 & 0.458 & $12.8 \%$ \\
\hline Support for tourism development & 0.4899 & / & / & $48.9 \%$ \\
\hline $\mathrm{H} 3(+)$ :Perceptions of rural tourism benefits $\rightarrow$ Support for tourism development & / & 0.3352 & 0.5956 & $19.3 \%$ \\
\hline $\mathrm{H} 5(+)$ :Quality of residents'life $\rightarrow$ Support for tourism development & / & 0.3623 & 0.532 & $22.2 \%$ \\
\hline $\mathrm{H} 2(+)$ : Attachment to rural community $\rightarrow$ Support for tourism development & / & 0.1079 & 0.4625 & $7.4 \%$ \\
\hline
\end{tabular}

Note: $(+)$ refers to positive relationship between two constructs.

The results in Table 7 and Figure 1 indicated that all proposed hypothesis were confirmed, by checking the direct effects among variables and significance of their paths. Furthermore, the results pointed out that the proposed model gained the high degree of validation.

Table 7. Results for the proposed hypothesis.

\begin{tabular}{|c|c|c|c|}
\hline Hypothesis & $\begin{array}{c}\text { Coefficient of Proposed } \\
\text { Connections }\end{array}$ & t-Value & Confirmation \\
\hline $\mathrm{H} 1(+)$ : Attachment to rural community $\rightarrow$ Perceptions of rural tourism benefits & $0.5488^{* * *}$ & 4.5438 & Yes \\
\hline $\mathrm{H} 3(+)$ : Perceptions of rural tourism benefits $\rightarrow$ Support for tourism development & $0.3352 * * *$ & 4.6137 & Yes \\
\hline $\mathrm{H} 4(+)$ : Perceptions of rural tourism benefits $\rightarrow$ Quality of residents' life & $0.458^{* * *}$ & 4.3013 & Yes \\
\hline
\end{tabular}

Note: $(+)$ refers to positive relationship between two constructs; ${ }^{*} p<0.05 ;{ }^{* * *} p<0.001$. 


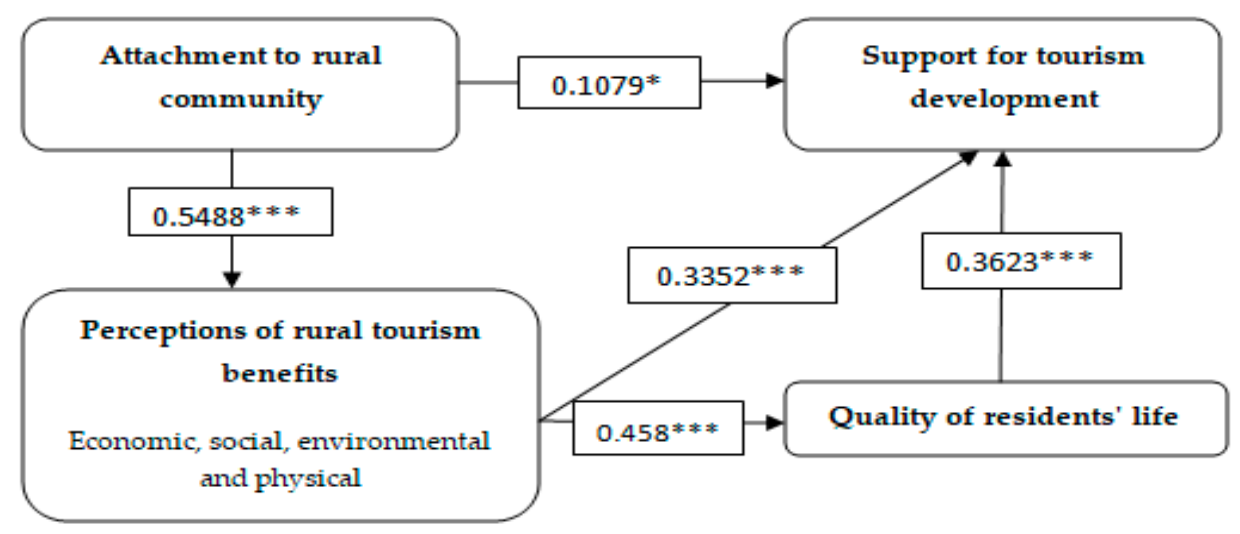

Figure 1. Graphical presentation of results for the proposed hypothesis. Note: ${ }^{*} p<0.05 ;{ }^{* *} p<0.001$.

The analysis showed that rural residents who were attached to the area where they lived were aware of the benefits tourism can bring and also that community attachment can have a positive impact on residents' perceptions; thus, Hypothesis 1 was accepted. These findings were in accordance with results from some previous research $[8,31,38]$. These results indicated that if residents were more attached to their community, they will be more aware of tourism impacts and consider more carefully if tourism development will bring benefits to the place where they live. Community attachment was positively related to residents' attitudes towards tourism benefits but this relationship is also valuable for creating good relations between locals and tourists, since a friendly and honest local community is more attractive to tourists [70]. Continuous evaluation of residents' attachment and their attitudes towards tourism can be accomplished by implementing different monitoring programs. In order to intensify residents' attachment to their community, the results of the study are helpful in creating campaigns for behavioral changes or different education and training programs (for example for working in the tourism sector). Enhancement of residents' attachment to a place can increase their motivation to actively participate in making decisions or to participate in other activities that will improve the quality of their environment. Analysis of the connection between residents' attachment and their support for tourism development found that there was a positive correlation among these two constructs. These results were similar with those that can be found in the research carried out by Nicholas, Thapa, and Ko [65]; thus, hypothesis 2 was accepted. Positively related community attachment and support for tourism development can be interpreted as the more attached someone is to his/her environment, the more he/she will support the development of tourism. These results should be taken with caution since these people are more concerned about their community and want only those activities that will be beneficial to the place where they live [25]. Although some research showed that those residents who lived in a community for long had negative attitudes towards tourism, and it was unlikely that they will support its development $[44,71]$, results from this research revealed that the longer someone resides in the community, the more willing he/she will be to support tourism development. These results are in line with some previous research [49,72].

Although the authors of this paper observed only positive impacts of tourism (the differences between positive and negative tourism impact have not been made), it was shown that positive perceptions on four groups of impacts will lead to the tendency of residents to support tourism development. These results were in line with previous research [37,40]; thus, Hypothesis 3 was accepted. The attitudes of local community can be a valuable source for making development plans, improving sustainability of tourism activities or for reducing negative impacts of tourism. Tourism planners need to be aware that residents will support tourism development if they perceive that tourism brings positive changes to their local economy and/or environment (these positive changes can be new business opportunities, cultural exchange, improvement of environmental conditions, etc). Residents will support tourism development if tourism policies are based on honesty, 
transparency, community needs, and if residents are provided with reliable information. Additionally, planners need to find a proper way to share tourism benefits equally between individuals of all social spectrums. Monitoring residents' attitudes and perceptions should be implemented in a long-term period, continuously.

Hypothesis 4 was also accepted, since the results showed that if the rural tourism development was based on sustainable basis it can have positive environmental, social, and other benefits for the community and enhance their quality of life. The results of this study highlighted the importance of protecting those elements that can be endangered by tourism development-natural and built landscapes as place characteristics and all other factors that reflect a place's character. Planned development in rural places, like those in Serbia, will ensure preservation of place attributes that residents are attached to. The findings of this study are useful for rural places whose offer is based on natural amenities and cultural heritage. As shown in this and confirmed in other research [51,73], perceptions of tourism benefits will be reflected on quality of residents' life only if residents were engaged or benefited from tourism. Local infrastructure improvement and better image of the community were significant benefits of tourism development that can enhance quality of residents' life. While Nunkoo and Fung [57] couldn't find a link between how satisfied residents were with the quality of their life on one side and support for tourism development on the other side, this research showed that there was a positive correlation between these two constructs. The elements of local community, especially those whose development may be directly affected by tourism development and that can enhance quality of residents' life, like infrastructure, possibilities for entertainment, preserved culture, and tradition, can encourage locals to have a positive attitude towards the development of tourism in their environment [10,74].

\section{Conclusions}

The study provided evidence of a positive relation between residents' perceived value towards tourism development, their attachment to the community, overall quality of life and support for sustainable tourism development. In order to evaluate the degree of residents' support for tourism development, the perceived value indicators, such as different benefits from tourism, were used. The results highlighted that perceived tourism benefits were important for evaluating tourism development and overall quality of residents' life. The community positively perceived tourism and its development, expecting that in future its development will increase quality of residents' life. Positive connection among residents' perceptions and level of their support for tourism in rural areas of Serbia showed that most of the residents were tourist oriented and that they think the current level of tourism was compatible with the characteristics of the area. Furthermore, these results were supported by the fact that residents' attachment to community positively correlated with residents' perceptions towards tourism development. The study provided better understanding of the factors that can have impact on residents' attitudes in relation to tourism and highlighted the importance of paying attention to local community as one of the most significant players for tourism development, especially in those regions that want to boost its economy by developing sustainable tourism.

Several limitations have emerged from the research and they can be taken into the consideration for some future research. Since the overall quality of residents'life was used for the research, in future, this component may include various aspects like health and safety, how connected community members are, and material and emotional aspects. Beside community attachment, it would be useful to use factors such as sense of a place, or factors that influence residents' support for tourism can be expanded on, such as those residents' personality and demographic information (for example, if residents are involved in tourism or not) as well as the type of destination. The research was conducted during high season, but it is recommended to analyze residents' perceptions and attitudes during low season to see if there were differences in attitudes towards tourism during various time frames. 
Supplementary Materials: The following are available online at http://www.mdpi.com/2071-1050/12/22/9438/s1, Table S1: Questionnaire.

Author Contributions: Conceptualization, D.D.B. and M.C.; methodology, T.N.T.; software, M.C.; validation, A.R. and Y.A.S.; formal analysis, D.D.B.; investigation, A.R. and M.C.; resources, D.D.B.; data curation, Y.A.S.; writing-original draft preparation, D.D.B. and M.C.; writing—review and editing, T.N.T. and Y.A.S. All authors have read and agreed to the published version of the manuscript.

Funding: This research received no external funding.

Conflicts of Interest: The authors declare no conflict of interest.

\section{References}

1. Davis, J.S.; Morais, D. Fraction and Enclaves: Small Towns and Socially Unsustainable Tourism Development. J. Travel Res. 2004, 43, 3-10. [CrossRef]

2. Ko, D.W.; Stewart, W. A Structural Equation Model of Residents' Attitudes for Tourism Development. Tour. Manag. 2002, 23, 521-530. [CrossRef]

3. Nunkoo, R.; Ramkissoon, H. Small Island Urban Tourism: A Residents' Perspective. Curr. Issue Tour. 2010, 13, 37-60. [CrossRef]

4. Sirakaya, E.; Teye, V.; Sónmez, S. Understanding Residents' Support for Tourism Development in the Central Region of Ghana. J. Travel Res. 2002, 41, 57-67. [CrossRef]

5. Andereck, K.; Valentine, K.; Knopf, R.; Vogt, C. Residents' Perceptions of Community Tourism Impacts. Ann. Tour. Res. 2005, 32, 1056-1076. [CrossRef]

6. Gursoy, D.; Rutherford, D. Host Attitudes toward Tourism: An Improved Structural Model. Ann. Tour. Res. 2004, 31, 495-516. [CrossRef]

7. Scaglione, A.; Mendola, D. Measuring the Perceived Value of Rural Tourism: A Field Survey in the Western Sicilian Agritourism Sector. Qual. Quant. 2017, 51, 745-763. [CrossRef]

8. Lee, T.H. Influence Analysis of Community Resident Support for Sustainable Tourism Development. Tour. Manag. 2013, 34, 37-46. [CrossRef]

9. McGehee, N.; Andereck, K. Factors Predicting Rural Residents' Support of Tourism. J. Travel Res. 2004, 43, 131-140. [CrossRef]

10. Woo, E.; Kim, H.; Uysal, M. Life Satisfaction and Support for Tourism Development. Ann. Tour. Res. 2015, 50, 84-97. [CrossRef]

11. Ramseook-Munhurrun, P.; Naidoo, P. Residents' Attitudes toward Perceived Tourism Benefits. Int. J. Manag. Mark. Res. 2011, 4, 45-56.

12. Mohammadi, M.; Khalifah, Z.; Hosseini, H. Local People Perceptions toward Social, Economic and Environmental Impacts of Tourism in Kermanshah (Iran). Asian Soc. Sci. 2010, 6, 220-225. [CrossRef]

13. Sweeney, J.; Soutar, G. Consumer Perceived Value: The Development of a Multiple Item Scale. J. Retail. 2001, 77, 203-220. [CrossRef]

14. Samantaray, L.L. Sustainable Rural Tourism: An Enabler for the Trend of Reverse Migration in Odisha. Int. J. Appl. Res. 2016, 2, 159-163.

15. Grgić, I.; Hadelan, L.; Krznar, S.; Zrakić, M. Could Rural Tourism Revitalize Rural Areas in Croatia? Agroeconomia Croatica 2017, 7, 98-108.

16. Neumeier, S.; Pollermann, K. Rural Tourism as Promoter of Rural Development-Prospects and Limitations: Case Study Findings from a Pilot Project Promoting Village Tourism. Eur. Countrys. 2014, 4, 270-296. [CrossRef]

17. McAreavey, R.; McDonagh, J. Sustainable Rural Tourism: Lessons for Rural Development. Sociologia Ruralis 2010, 51, 175-194. [CrossRef]

18. Nyaupane, G.; Poudel, S. Linkages among Biodiversity, Livelihood, and Tourism. Ann. Tour. Res. 2011, 38, 1344-1366. [CrossRef]

19. Giampiccoli, A.; Kalis, J. Community-Based Tourism and Local Culture: The Case of the Amampondo. Rev. Tur. Patrim. Cult. 2012, 10, 173-188. [CrossRef]

20. Bogdanov, N. Mala Ruralna Domaćinstva u Srbiji i Ruralna Nepoljoprivredna Ekonomija (Small Rural Households in Serbia and Rural Non-Farm Economy); UNDP: Belgrade, Serbia, 2007. 
21. Jelić, S.; Kolarević, V. Fenomen Socijalne Isključenosti u Periodu Tranzicije u Srbiji (The Phenomenon of Social Exclusion in the Period of Transition in Serbia). Sociol. Pregl. 2016, L, 209-228. [CrossRef]

22. Marques, H.R. Desarrollo Locala Escala Humana (Local Development at a Human Scale). Polis 2009, 22, 137-158.

23. Belij, S. Razvoj Autentičnog Eko-Ruralnog Turizma u Srbiji kao Model za Pravilno Pozicioniranje u Procesu Tranzicije (Development of Authentic Eco-Rural Tourism in Serbia as a Model for Proper Positioning in the Process of Transition). Zaštita Prirode 2003, 54, 55-61.

24. Kyle, G.; Bricker, K.; Graefe, A.; Wickham, T. An examination of recreationists' relationships with activities and settings. Leis. Sci. 2004, 26, 123-142. [CrossRef]

25. Eslami, S.; Khalifah, Z.; Mardani, A.; Streimikiene, D.; Han, H. Community attachment, tourism impacts, quality of life and residents' support for sustainable tourism development. J. Travel Tour. Mark. 2019, 36, 1061-1079. [CrossRef]

26. Adeniran, A.J.; Akinlabi, F.J. Perceptions on Cultural Significance and Heritage Conservation: A Case Study of Sussan Wenger's Building, Osogbo, Nigeria. Afr. J. Hist. Cult. 2011, 3, 73-88.

27. Brehm, J.; Eisenhauer, B.; Krannich, R. Dimensions of Community Attachment and Their Relationship to Well-Being in the Amenity-Rich Rural West. Rural Sociol. 2004, 69, 405-429. [CrossRef]

28. Rasoolimanesh, M.; Jaafar, M.; Kock, N. A Revised Framework of Social Exchange Theory to Investigate the Factors Influencing Residents' Perceptions. Tour. Manag. Perspect. 2015, 16, 335-345. [CrossRef]

29. Larson, S.; De Freitas, D.; Hicks, C. Sense of Place as a Determinant of People's Attitudes towards the Environment: Implications for Natural Resources Management and Planning in the Great Barrier Reef, Australia. J. Environ. Manag. 2013, 117, 226-234. [CrossRef]

30. Devine-Wright, P. Rethinking Nimbyism: The Role of Place Attachment and Place Identity in Explaining Place-Protective Action. J. Commun. Appl. Soc. Psychol. 2009, 19, 426-441. [CrossRef]

31. Adongo, R.; Choe, J.Y.; Han, H. Tourism in Hoi An, Vietnam: Impacts, perceived benefits, community attachment and support for tourism development. Int. J. Tour. Sci. 2017, 17, 86-106. [CrossRef]

32. Chen, C.F.; Chen, P.C. Resident Attitudes toward Heritage Tourism Development. Tour. Geogr. 2010, 12, 525-545. [CrossRef]

33. Draper, J.; Woosnam, K.; Norman, W. Tourism Use History: Exploring a New Framework for Understanding Residents' Attitudes toward Tourism. J. Travel Res. 2011, 50, 64-77. [CrossRef]

34. Gursoy, D.; Jurowski, C.; Uysal, M. Resident Attitudes: A Structural Modeling Approach. Ann. Tour. Res. 2002, 29, 79-105. [CrossRef]

35. Ramkissoon, H.; Weiler, B.; Smith, L. Place Attachment, Place Satisfaction and Pro-Environmental Behaviour: A Comparative Assessment of Multiple Regression and Structural Equation Modeling. J. Policy Res. Tour. Leis. Events 2013, 5, 215-232. [CrossRef]

36. Gursoy, D.; Chi, C.; Dyer, P. Locals' Attitudes toward Mass and Alternative Tourism: The Case of Sunshine Coast, Australia. J. Travel Res. 2010, 49, 381-394. [CrossRef]

37. Nunkoo, R.; Gursoy, D. Residents' Support for Tourism: An Identity Perspective. Ann. Tour. Res. 2012, 39, 243-268. [CrossRef]

38. Brida, J.G.; Disegna, M.; Osti, L. Residents' Perceptions of Tourism Impacts and Attitudes Towards Tourism Policies. Tour. Int. Multidiscip. J. Tour. 2014, 9, 37-71.

39. Lin, Z.; Chen, Y.; Filieri, R. Resident-tourist value co-creation: The role of residents' perceived tourism impacts and life satisfaction. Tour. Manag. 2017, 61, 436-442. [CrossRef]

40. Stylidis, D.; Biran, A.; Sit, J.; Szivas, E.M. Residents' support for tourism development: The role of residents' place image and perceived tourism impacts. Tour. Manag. 2014, 45, 260-274. [CrossRef]

41. Long, P.H.; Kayat, K. Residents' perceptions of tourism impact and their support for tourism development: The case study of Cuc Phuong National Park, Ninh Binh province, Vietnam. Eur. J. Tour. Res. 2011, 4, 123-146.

42. Harrill, R.; Potts, T. Tourism planning in historic districts. Attitudes toward tourism development in Charleston. J. Am. Plan. Assoc. 2003, 69, 233-244. [CrossRef]

43. Latkova, P.; Vogt, C. Residents' Attitudes toward Existing and Future Tourism Development in Rural Communities. J. Travel Res. 2012, 51, 50-67. [CrossRef]

44. Byrd, E.; Gustke, L. Using Decision Trees to Identify Tourism Stakeholders: The Case of Two Eastern North Carolina Counties. Tour. Hosp. Res. 2004, 7, 176-193. [CrossRef] 
45. Kim, K.; Uysal, M.; Sirgy, J. How Does Tourism in a Community Impact the Quality of Life of Community Residents? Tour. Manag. 2013, 36, 527-540. [CrossRef]

46. Kaplanidou, K.; Karadakis, K.; Gibson, H.; Thapa, B.; Walker, M.; Geldenhuys, S.; Coetzee, W. Quality of Life, Event Impacts, and Mega-event Support among South African Residents before and after the 2010 FIFA World Cup. J. Travel Res. 2013, 52, 631-645. [CrossRef]

47. Nawijn, J.; Mitas, O. Resident Attitudes to Tourism and Their Effect on Subjective Well-Being: The Case of Palma de Mallorca. J. Travel Res. 2012, 51, 531-541. [CrossRef]

48. Yu, C.P.; Cole, S.; Chancellor, C. Resident support for tourism development in rural mid western (USA) communities: Perceived tourism impacts and community quality of life perspective. Sustainability 2018, 10, 802. [CrossRef]

49. Gursoy, D.; Ouyang, Z.; Nunkoo, R.; Wei, W. Residents' impact perceptions of and attitudes towards tourism development: A meta-analysis. J. Hosp. Mark. Manag. 2018, 28, 306-333. [CrossRef]

50. Andereck, K.; Vogt, C. The Relationship between Residents' Attitudes toward Tourism and Tourism Development Options. J. Travel Res. 2000, 39, 27-36. [CrossRef]

51. Liang, Z.X.; Hui, T.K. Residents' quality of life and attitudes toward tourism development in China. Tour. Manag. 2016, 57, 56-67. [CrossRef]

52. Andereck, K.L.; Nyaupane, G.P. Exploring the Nature of Tourism and Quality of Life Perceptions among Residents. J. Travel Res. 2011, 50, 248-260. [CrossRef]

53. Jeon, M.M.; Kang, M.M.; Desmarais, E. Residents' Perceived Quality of Life in a Cultural-Heritage Tourism Destination. Appl. Res. Qual. Life 2014, 11, 105-123. [CrossRef]

54. Strzelecka, M.; Boley, B.B.; Strzelecka, C. Empowerment and resident support for tourism in rural Central and Eastern Europe (CEE): The case of Pomerania, Poland. J. Sustain. Tour. 2017, 25, 554-572. [CrossRef]

55. Bitsani, E.; Kavoura, A. Host Perceptions of Rural Tour Marketing to Sustainable Tourism in Central Eastern Europe. The Case Study of Istria, Croatia. Procedia-Soc. Behav. Sci. 2014, 148, 362-369. [CrossRef]

56. Michalkó, G.; Bakucz, M.; Rátz, T. The relationship between tourism and residents' quality of life: A case study of Harkány, Hungary. Eur. J. Tourism Res. 2013, 6, 154-169.

57. Nunkoo, R.; Fung, S.K. Residents' Support for Tourism: Testing Alternative Structural Models. J. Travel Res. 2015, 55, 1-15. [CrossRef]

58. Statistical Office of the Republic of Serbia. Census Atlas 2011-Census of Population and Housing 2011 in the Republic of Serbia; Statistical Office of the Republic of Serbia: Belgrade, Serbia, 2014.

59. Novković, N.; Mutavdžić, B.; Vukelić, N. Vojvodina's Agriculture-Analysis and Possibilities. In Agriculture and Rural Development-Challenges of Transition and Integration Processes; Bogdanov, N., Stevanović, S., Eds.; University of Belgrade: Belgrade, Serbia, 2013; pp. 90-97.

60. Bogdanov, N.; Cvejić, S. Poverty and Social Exclusion in Rural Serbia-Position of Family Farmers. Econ. Agric. 2011, LVIII(2), 3-15.

61. Petrović, M.; Blešić, I.; Ivolga, A.; Vujko, A. Agritourism Impact Toward Locals' Attitudes-An Evidence from Vojvodina Province (Serbia). J. Geogr. Inst. "Jovan Cvijić" Sasa 2016, 66, 105-123. [CrossRef]

62. Petrović, M.; Blešić, I.; Vujko, A.; Gajić, T. The Role of Agritourism's Impact on the Local Community in a Transitional Society: A Report from Serbia. Transylv. Rev. Adm. Sci. 2017, 13, 146-163. [CrossRef]

63. Petrović, M.D.; Gelbman, A.; Demirović, D.; Gagić, S.; Vuković, D. The Examination of the Residents' Activities and Dedication to the Local Community-An Agritourism Access to the Subject. J. Geogr. Inst. "Jovan Cvijić" Sasa 2017, 67, 37-52. [CrossRef]

64. Abdollahzadeh, G.; Sharifzadeh, A. Rural Residents' Perceptions toward Tourism Development: A Study from Iran. Int. J. Tour. Res. 2014, 16, 126-136. [CrossRef]

65. Nicholas, L.N.; Thapa, B.; Ko, Y.J. Residents' Perspectives of a World Heritage Site: The Pitons Management Area, St. Lucia. Ann. Tour. Res. 2009, 36, 390-412. [CrossRef]

66. Ciavolino, E.; Nitti, M. Using the Hybrid Two-Step Estimation Approach for the Identification of Second-Order Latent Variable Models. J. Appl. Stat. 2013, 40, 508-526. [CrossRef]

67. Wright, R.; Campbell, D.; Thatcher, J.; Roberts, N. Operationalizing Multidimensional Constructs Instructural Equation Modeling: Recommendations for IS Research. Commun. Assoc. Inf. Syst. 2012, 40, 367-412. [CrossRef]

68. Hair, J.; Ringle, C.; Sarstedt, M. PLS-SEM: Indeed a Silver Bullet. J. Mark. Theory Pract. 2011, 19, 139-151. [CrossRef] 
69. MacKenzie, S.; Podsakoff, P.; Jarvis, C. The Problem of Measurement Model Misspecification in Behavioral and Organizational Research and Some Recommended Solutions. J. Appl. Psychol. 2005, 90, 710-730. [CrossRef]

70. Dodds, R.; Butler, R. Barriers to implementing sustainable tourism policy in mass tourism destinations. Tourismos 2010, 5, 35-54.

71. Eusebio, C.; Vieira, L.A.; Lima, S. Place attachment, host-tourist interactions, and residents' attitudes towards tourism development: The case of Boa Vista Island in Cape Verde. J. Sustain. Tour. 2018, 26, 890-909. [CrossRef]

72. Hwang, S.N.; Lee, C.; Chen, H.J. The relationship among tourists' involvement, place attachment and interpretation satisfaction in Taiwan's national parks. Tour. Manag. 2005, 26, 143-156. [CrossRef]

73. Maruyama, N.; Woosnam, K.M. Residents' ethnic attitudes and support for ethnic neighborhood tourism: The case of a Brazilian town in Japan. Tour. Manag. 2015, 50, 225-237. [CrossRef]

74. Boley, B.B.; Ayscue, E.; Maruyama, N.; Woosnam, K.M. Gender and empowerment: Assessing discrepancies using the resident empowerment through tourism scale. J. Sustain. Tour. 2016, 25, 113-129. [CrossRef]

Publisher's Note: MDPI stays neutral with regard to jurisdictional claims in published maps and institutional affiliations.

(C) 2020 by the authors. Licensee MDPI, Basel, Switzerland. This article is an open access article distributed under the terms and conditions of the Creative Commons Attribution (CC BY) license (http://creativecommons.org/licenses/by/4.0/). 